\title{
FAKTOR - FAKTOR YANG BERHUBUNGAN DENGAN STATUS IMUNISASI DASAR PADA BAYI DI DESA RENGASDENGKLOK SELATAN KABUPATEN KARAWANG
}

\author{
Correlation Factors With Basic Immunization Status in Infants in South \\ Rengasdengklok, Karawang Distric \\ Mardianti ${ }^{1}$ Yuli Farida ${ }^{2}$ \\ Prodi Kebidanan Karawang Poltekkes Kemenkes Bandung \\ (farahfahri@gmail.com)
}

\begin{abstract}
ABSTRAK
Latar belakang : Upaya menurunkan angka kesakitan dan kematian pada bayi dan balita salahsatunya adalah dengan imunisasi. Pada awal kehidupan bayi sangat rentan terkena penyakit, apabila bayi terkena penyakit maka akan menyebabkan gangguan fisik, mental, kecacatan, dan menimbulkan kematian. Imunisasi merupakan upaya promotif dan preventif dalam mencegah penularan penyakit pada bayi dan balita.

Tujuan : Mengetahui faktor - faktor yang berhubungan dengan status imunisasi dasar pada bayi

Metode: Penelitian analitik dengan pendekatan Cross sectional,. Populasi penelitian seluruh ibu bayi sampai dengan usia anak 2 tahun di Desa Rengasdengklok Selatan. Pengambilan sampel dengan teknik simple random sampling. Pengumpul data primer denganwawancara dan kuesioner, serta data sekunder dengan melihat Kartu Menuju Sehat bayi. Analisa data dengan Uji Chisquare.

Hasil : Karakteristik responden 82,5\% pendidikan rendah dan 91,3\% ibu tidak bekerja. Status imunisasi bayi lengkap sebesar 61,3\%, dan 50\% ibu memiliki pengetahuan baik tentang imunisasi, sebesar 53,8\% ibu mendapatkan dukungan keluarga melakukan imunisasi, 75\% tradisi keluarga tidak mendukung imunisasi, ibu memiliki sikap positif terhadap imunisasi sebanyak $52,5 \%$, terdapat $88,8 \%$ ibu bayi yang belum mendapatkan informasi imunisasi, 58,8\% ibu memiliki motivasi rendah untuk melakukan imunisasi, $90 \%$ peran petugas aktif melaksanakan imunisasi, $92,5 \%$ sarana kesehatan telah tersedia untuk melaksanakan imunisasi, serta $87,5 \%$ ibu bayi menyatakan jarak layanan kesehatan dekat. Faktor pendidikan, pengetahuan, pekerjaaan, dukungan keluarga, tradisi, siakp, informasi, motivasi, sarana kesehatan, peran petugas kesehatan serta jarak layanan kesehatan tidak berhubungan dengan status imunisasi dasar pada bayi.
\end{abstract}

Simpulan: Tidak ada hubungan faktor determinan dengan status imunisasi dasar pada bayi.

Kata Kunci : Faktor Determinan, Status Imunisasi Bayi. 


\begin{abstract}
Background: One of the efforts to reduce morbidity and mortality in infants and toddlers is immunization. Early in life babies are very susceptible to disease, if the baby is affected by the disease it will cause physical, mental, disability, and cause death. Immunization is a promotive and preventive effort in preventing disease transmission to infants and toddlers.

The Aim: To determine factors related to basic immunization status in infants.

Method: Analytical research with cross sectional approach ,. The study population was all infant mothers up to the age of 2 years old children in Rengasdengklok Selatan Village. Sampling with simple random sampling technique. Primary data collector with interviews and questionnaires, as well as secondary data by looking at the baby's Health Card. Analyze data with the Chisquare Test.

Results: Characteristics of respondents $82.5 \%$ of low education and $91.3 \%$ of unemployed mothers. Complete infant immunization status was $61.3 \%$, and $50 \%$ of mothers had good knowledge about immunization, $53.8 \%$ of mothers received family support for immunization, $75 \%$ of family traditions did not support immunization, mothers had a positive attitude towards immunization as much as $52.5 \%$, there are $88.8 \%$ of baby mothers who have not received immunization information, $58.8 \%$ of mothers have low motivation to carry out immunizations, $90 \%$ of the role of active officers carrying out immunizations, $92.5 \%$ of health facilities are available to carry out immunizations, and $87,5 \%$ of baby mothers stated that the distance of health services was close. The factors of education, knowledge, employment, family support, tradition, attitude, information, motivation, health facilities, the role of health workers and distance of health services are not related to basic immunization status in infants.
\end{abstract}

Conclusion: There is no correlation between determinant factors with basic immunization status in infants.

Keywords: Determinant Factors, Baby Immunization Status.

\title{
PENDAHULUAN
}

Imunisasi merupakan salahsatu cara yang efektif untuk mencegah penularan penyakit dan upaya menurunkan angka kesakitan dan kematian pada bayi dan balita. Pentingnya imunisasi didasarkan pada pemikiran paradigma sehat bahwa upaya promotif dan preventif merupakan hal penting dalam peningkatan status kesehatan.

Pada awal kehidupan bayi sangat rentan terkena penyakit tersebut, apabila bayi terkena penyakit tersebut maka akan menyebabkan gangguan fisik, mental, kecacatan, dan menimbulkan kematian. Salah satu upaya untuk menjadikan generasi yang sehat yaitu dengan mengurangi tingkat morbiditas dan mortalitas pada anak. Selain itu juga dibutuhkan suatu upaya kesehatan yang konsisten (Soetjiningsih, 2012). 
Berdasarkan hasil Riset kesehatan Dasar (Riskesdas) tahun 2013 cakupan pemberian imunisasi lengkap baru mencapai 59,2 \%. Imunisasi dasar sangat penting diberikan pada bayi usia 0-11 bulan untuk memberikan kekebalan dari penyakit yang dapat dicegah dengan imunisasi (PD3I) antaralain penyakit Tuberkulosis, difteri, Pertusis, Tetanus, polio, hepatitis B, dan Campak (Depkes, 2015). Pencapaian kegiatan imunisasi berpedoman pada UCI (Universal Child Immunization). Target nasional UCI pada tahun 2014 adalah 100\% dan target imunisasi di Jawa Barat tahun 2015 adalah 90,5\%,serta standar minimal cakupan imunisasi lengkap pada bayi adalah 80\%. (Kemenkes, 2010).

Rendahnya cakupan imunisasi dasar lengkap merupakan permasalahan yang segera harus diatasi, selain memiliki manfaat, imunisasi juga menimbulkan efek samping dalam pelaksanaannya dalam dunia kesehatan fenomena ini dikenal juga dengan istilah adverse event atau lebih dikenal dengan kejadian pasca imunisasi (KIPI). Berdasarkan penelitian yang dilakukan (Friedrickson, et al, 2004). Menunjukkan bahwa orangtua menolak orangtua menolak untuk memberikan imunisasi kepada anaknya dikarenakan kurangnya pemahaman oarngtua tentang pentingnya imunisasi bagi anak dan orangtua merasa khawatir mengenai efek samping yang ditimbulkan setelah imunisasi sebab orangtua takut anaknya sakit. Berdasarkan data Riskesdas (2013), sebanyak 8.7\% anak usia 1223 bulan di Indonesia belum pernah mendapatkan imunisasi. Alasan utama untuk tidak mengimunisasikan anak karena orang tua takut anak menjadi panas.

Perilaku seseorang dalam mengikuti anjuran tenaga kesehatan dapat dipengaruhi oleh beberapa faktor seperti keyakinan, persepsi individu tentang keefektifan vaksin, sikap orang tua dan keluarga serta penyedia layanan imunisasi (Katz et al., 2010 dalam Handayani 2008). Pelayanan dari petugas kesehatan mempengaruhi ibu dalam mengimunisasikan anaknya, dan pelayanan yang baik dari tenaga kesehatan mendorong ibu untuk mengikuti anjuran dari tenaga kesehatan (Achmadi, 2006). Ibu yang tidak mendapatkan dukungan dari tenaga kesehatan 5.9 kali berisiko tidak mengimunisasikan anaknya (Tampemawa, 2013). Apabila ibu tidak mengetahui tentang imunisasi, maka anak kemungkinan tidak akan mendapat imunisasi lengkap (Ningrum, 2014). Oleh karena itu peran tenaga kesehatan dapat mempengaruhi ibu dalam mengimunisasikan anaknya. Tenaga kesehatan dapat memberikan edukasi, dukungan serta informasi tentang imunisasi kepada ibu.

Menurut Sudarti, 2012 bahwa pada keadaan tertentu imunisasi tidak dapat dilaksanakan sesuai dengan jadwal yang sudah disepakati, keadaan ini tidak merupakan hambatan untuk melanjutkan imunisasi. Vaksin yang sudah diterima oleh anak tidak menjadi hilang manfatnya tetapi sudah menghasilkan respons imunologis sebagaimana yang diharapkan tetapi belum mempunyai antibody yang optimal karena belum mendapatkan imunisasi yang lengkap, sehingga kadar antibodi yang dihasilkan masih dibawah kadar ambang perlindungan (protective level) atau belum mencapai kadar antibodi yang memberikan perlindungan untuk kurun waktu yang lengkap (live long immunity) sebagaimana imunisasi lengkap, sehingga petugas kesehatan wajib menyelesaikan jadwal imunisasi dengan cara melanjutkan imunisasi yang belum lengkap, mengantisipasinya dengan pemberian imunisasi booster pada usia prasekolah dan program BIAS pada anak sekolah.

Faktor - Faktor Yang Berhubungan Dengan Status Imunisasi Dasar Pada Bayi Di 
Desa Rengasdengklok Selatan merupakan desa yang termasuk dalam wilayah kerja Puskesmas Rengasdengklok. Puskesmas Rengasdengklok ini, terpilih dalam program pendampingan KIA Kementerian Kesehatan pada tahun 2017 yang ditunjuk oleh Dinas Kesehatan Kabupaten Karawang, berdasarkan hasil pendampingan pada balita melalui wawancara, sebagian besar ibu balita menyatakan bahwa banyak bayi yang belum di imunisasi atau belum lengkap di imunisasi.Data dari profil Puskesmas Rengasdengklok tahun 2016, dari 6 desa yang ada di Rengasdengklok diketahui bahwa, desa yang memiliki nilai cakupan imunisasi lengkap terendah (72,71\%) pada bayi dengan jumlah sasaran bayi 601 adalah Desa Rengasdengklok Selatan. Oleh karena itu, maka peneliti tertarik melakukan penelitian dengan judul " Faktor - faktor yang Berhubungan dengan Status Imunisasi Dasar Pada Bayi di Desa Rengasdengklok Selatan Kabupaten Karawang".

\section{METODE PENELITIAN}

Desain penelitian yang digunakan dalam penelitian ini adalah observasional Analitik dengan pendekatan Cross sectional. Populasi pada penelitian ini adalah seluruh ibu yang mempunyai bayi usia 1- 2 tahun di wilayah Desa RengasdengklokSelatan bulan Maret sampai dengan Oktober 2018. Pengambilan sampel berdasarkan perhitungan rumus besar sampel, maka jumlah sampel minimal yang diperlukan adalah sebesar 73 responden, kemudian ditambah $10 \%$ untuk mencegah sampel drop out, sehingga jumlah sampel minimal sebesar 80 responden.Cara pengambilan sampel pada penelitian ini adalah Simple Random Sampling. Metode penetapan sampel yaitu semua ibu yang mempunyai bayi usia 1- 2 tahun di Desa Rengasdengklok Selatan Kabupaten Karawang pada saat penelitan datang ke posyandu dirandom secara acak untuk dijadikan sampel penelitian.Instrumen penelitian ini menggunakan kuesioner dan wawancara. Dilakukan uji validitas kuesioner sebelum dilakukan penelitian pada desa yang homogenitasnya hampir sama dan dilakukan penghitungan uji validitas dengan sistem komputerisasi, setelah semua pertanyaan dinyatakan valid maka kuesioner bisa digunakan untuk penelitian yang sebenarnya.

Tehnik Pengumpulan data, Cara pengambilan data yang digunakan dalam penelitian ini adalah menggunakan data primer yang dilakukan melalui wawancara dan kuesioner, serta data sekunder didapat dari buku KMS bayi untuk memastikan kelengkapan status imunisasi.Pengolahan data dilakukan dengan beberapa tahap yaitu editing, coding, processing dan cleaning. Setelah data hasil penelitian semua terkumpul, maka peneliti melakukan analisis dengan sistem komputerisasi, dengan cara analisiss unavariat dan bivariat dengan Uji Chisquare. 


\section{HASIL DAN PEMBAHASAN}

\section{Hasil}

Pada penelitian ini diteliti sebanyak 80 responden. Karakteristik subjek penelitian dapat dilihat pada tabel- tabel dibawah ini:

Tabel 1: Distribusi Frekuensi Karakteristik Responden

\begin{tabular}{|c|c|c|}
\hline Karakteristik & Frekuensi (f) & Prosentase (\%) \\
\hline \multicolumn{3}{|l|}{ Status Imunisasi } \\
\hline Lengkap & 49 & $61,3 \%$ \\
\hline Tidak Lengkap & 31 & $38,8 \%$ \\
\hline \multicolumn{3}{|l|}{ Pendidikan } \\
\hline Lanjut & 14 & $17,5 \%$ \\
\hline Rendah & 66 & $82,5 \%$ \\
\hline \multicolumn{3}{|l|}{ Pengetahuan } \\
\hline Baik & 40 & $50 \%$ \\
\hline Kurang Baik & 40 & $50 \%$ \\
\hline \multicolumn{3}{|l|}{ Pekerjaan } \\
\hline Bekerja & 7 & $8,8 \%$ \\
\hline \multirow{2}{*}{\multicolumn{3}{|c|}{ Dukungan Keluarga }} \\
\hline & & \\
\hline Mendukung & 43 & $53,8 \%$ \\
\hline Tidak mendukung & 37 & $46,3 \%$ \\
\hline \multicolumn{3}{|l|}{ Tradisi Keluarga } \\
\hline Memberikan & 20 & $25 \%$ \\
\hline Tidak memberikan & 60 & $75 \%$ \\
\hline \multicolumn{3}{|l|}{ Sikap } \\
\hline Positif & 42 & $52,5 \%$ \\
\hline Negatif & 38 & $47,5 \%$ \\
\hline \multicolumn{3}{|l|}{ Informasi } \\
\hline Mendapatkan & 9 & $11,3 \%$ \\
\hline Tidak mendapatkan & 71 & $88.8 \%$ \\
\hline \multicolumn{3}{|l|}{ Motivasi } \\
\hline Tinggi & 33 & $41,3 \%$ \\
\hline Rendah & 47 & $58,8 \%$ \\
\hline \multicolumn{3}{|l|}{ Peran petugas } \\
\hline Aktif & 72 & $90 \%$ \\
\hline Tidak aktif & 8 & $10 \%$ \\
\hline \multicolumn{3}{|l|}{ Sarana Imunisasi } \\
\hline Ada & 74 & $92,5 \%$ \\
\hline Tidak ada & 6 & $7,5 \%$ \\
\hline \multicolumn{3}{|c|}{ Jarak Layanan Kesehatan } \\
\hline Dekat & 70 & $87,5 \%$ \\
\hline Jauh & 10 & $12,5 \%$ \\
\hline
\end{tabular}

Pada Tabel 1 dapat diketahui bahwa dari 80 responden sebagian besar mengimunisasikan lengkap bayinya yang berjumlah 49 responden $(61,3 \%)$, sebagian besar responden berpendidikan rendah sebanyak 66 orang $(82,5 \%)$, pada variabel pengetahuan diketahui bahwa ibu yang berpengetahuan baik dan berpengetahuan rendah sama banyak yaitu 40 responden (50\%), sedangkan untuk 
pekerjaan sebagian besar responden tidak bekerja yaitu $73(91,3 \%)$ responden. Sebagian besar responden mendapat dukungan keluarga untuk melakukan imunisasi yaitu 43 responden $(53,8 \%)$, tradisi keluarga menunjukkan bahwa sebagian besar keluarga tidak memberikan imunisasi pada bayinya yang berjumlah 60 responden (75\%). Pada variabel sikap diperoleh hasil bahwa lebih dari setengahnya yaitu 42 responden $(52,5 \%)$ bersikap positif terhadap imunisasi bayinya, sebagian besar ibu menyatakan tidak mendapatkan informasi tentang imunisasi berjumlah 71 responden $(88,8 \%)$, sedangkan untuk variabel motivasi diperoleh hasil bahwa sebagian besar memiliki motivasi rendah 58,8 \% (47 responden) . Pada variabel peran petugas kesehatan didapatkan hasil bahwa $90 \%$ ( 72 responden) menyatakan bahwa peran petugas aktif, sedangkan untuk variabel sarana imunisasi didapatkan hasil bahwa responden menyatakan tersedianya sarana kesehatan untuk melakukan imunisasi yaitu 74 responden $(92,5 \%)$ serta persepsi responden terhadap jarak tempuh layanan kesehatan untuk melakukan imunisasi sebagian besar menyatakan dekat yaitu 70 responden $(87,5 \%)$.

Tabel 2: Hubungan Pendidikan dengan Status Imunisasi

\begin{tabular}{llccc}
\hline Pendidikan & \multicolumn{2}{c}{ Status Imunisasi } & OR & P value \\
& Lengkap & Tidak Lengkap & & \\
\hline Rendah & $39(59,1 \%)$ & $27(40,9 \%)$ & 1,731 & 0,576 \\
Lanjut & $10(71,4 \%)$ & $4(28,6 \%)$ & & \\
Jumlah & $49(61,3 \%)$ & $31(38,8 \%)$ & & \\
\hline
\end{tabular}

Hasil analisis hubungan antara pendidikan dengan status imunisasi diketahuibahwa sebanyak $39(59,1 \%)$ ibu pendidikan rendah yang memberikan imunisasi lengkap pada bayinya. Sedangkan diantara ibu yang berpendidikan lanjut terdapat $10(71,4 \%)$ yang memberikan imunisasi lengkap pada bayinya. Hasil uji statistik diperoleh nilai $\mathrm{P}=0,576$ maka dapat disimpulkan tidak ada hubungan antara pendidikan dengan status imunisasi. Dari hasil analisis diperoleh $\mathrm{OR}=1.731$ artinya ibu yang berpendidikan lanjut mempunyai peluang $1,731 \mathrm{kali}$ untuk memberikan imunisasi pada bayinya dibanding ibu yang berpendidikan rendah.Hal ini tidak sesuai dengan teori Lawrence Green (1980) dalam Soekijdo Notoadmojo, 2003 yang menyatakan pendidikan merupakan faktor yang mempengaruhi prilaku seseorang. Teori menurut Juli Soemirat Slamet 2000 menyatakan bahwa seorang ibu dapat memelihara dan mendidik anaknya dengan baik apabila ia sendiri berpendidikan. Hasil penelitian ini sejalan dengan hasil penelitian yang dilakukan oleh Ponidjan, 2012 yang menyatakan bahwa tidak ada hubungan tingkat pendidikan ibu dengan status imunisasi bayi di wilayah kerja puskesmas Bahu kecamatan Malalayang. Hal ini dikarenakan walaupun ibu hanya memiliki dasar pendidikan yang rendah namun karena kemajuan teknologi dan informasi menyebabkan ibu terpapar dengan pentingnya imnusasi lengkap pada bayi yang diperoleh darimanapun misalnya media sosial dan media elektronik. 
Tabel 3: Hubungan Tingkat Pengetahuan dengan Status Imunisasi

\begin{tabular}{lllll}
\hline Pengetahuan & \multicolumn{2}{c}{ Status Imunisasi } & OR & ' value \\
& Lengkap & Tidak Lengkap & & \\
\hline Tinggi & $27(67,5 \%)$ & $13(32,5 \%)$ & 1,699 & 0,359 \\
Rendah & $22(55 \%)$ & $18(45 \%)$ & & \\
Jumlah & $49(61,3 \%)$ & $31(38,8 \%)$ & &
\end{tabular}

Hasil analisis hubungan antara pengetahuan dengan status imunisasi diketahuibahwa sebanyak $27(67,5 \%)$ ibu pengetahuan tinggi memberikan imunisasi lengkap kepada bayinya. Sedangkan diantara ibu yang berpengetahuan rendah hanya 22 responden (55\%) yang memberikan imunisasi lengkap pada bayinya. Hasil uji statistik diperoleh nilai $\mathrm{P}=0,359$ maka dapat disimpulkan tidak ada hubungan antara pengetahuan dengan status imunisasi. Dari hasil analisis diperoleh $\mathrm{OR}=1,699$ artinya ibu yang berpengetahuan tinggi mempunyai peluang 1,699 kali untuk memberikan imunisasi pada bayinya dibanding ibu yang berpengetahuan rendah.Hal ini tidak sejalan dengan teoriLawrence Green (1980) dalam Soekijdo Notoadmojo, 2003 dan WHO tahun 2009 yang melakukan reviewed terhadap beberapa artikel tentang epidemiology of the unimmunized child tahun 1999-2009 dan didapatkan bahwa pengetahuan orang tua merupakan salah satu faktor yang berhubungan dengan rendahnya angka imunisasi pada anak.Tidak sejalan juga dengan hasil penelitian Ningrum \& Sulastri tahun 2008 tentang faktor-faktor yang mempengaruhi kelengkapan imunisasi bayi di puskesmas Banyudono Kabupaten Boyolali yang menyatakan bahwa pengetahuan ibu berpengaruh terhadap kelengkapan imunisasi bayi.Menurut asumsi peneliti, hal ini terjadi karena signifikan dengan pendidikan responden yang sebagian besar rendah.

Tabel 4 : Hubungan Pekerjaan dengan Status Imunisasi

\begin{tabular}{lcccl}
\hline Pekerjaan & \multicolumn{2}{c}{ Status Imunisasi } & OR & P value \\
& Lengkap & Tidak Lengkap & & \\
\hline Bekerja & $5(71,4 \%)$ & $2(28,6 \%)$ & 1,648 & 0.700 \\
Tidak Bekerja & $44(60,3 \%)$ & $29(39,7 \%)$ & & \\
Jumlah & $49(61,3 \%)$ & $31(38,8 \%)$ & & \\
\hline
\end{tabular}

Hasil analisis hubungan antara pekerjaan dengan status imunisasi diketahui bahwa sebanyak 5 responden $(71,4 \%)$ ibu bekerja yang memberikan imunisasi lengkap kepada bayinya. Sedangkan ibu yang tidak bekerja berjumlah 44 responden $(60,3 \%)$ memberikan imunisasi lengkap pada bayinya. Hasil uji statistik diperoleh nilai $\mathrm{P}=0,700$ maka dapat disimpulkan tidak ada hubungan antara pekerjaan dengan status imunisasi. Dari hasil analisis diperoleh $\mathrm{OR}=1,648$ artinya ibu yang bekerja memiliki peluang 1,648 kali untuk memberikan imunisasi lengkap pada bayinya dibandingkan dengan ibu yang tidak bekerja. Hasil penelitian ini tidak sesuai dengan teori Panji Anoraga (2005) yang menyatakan bahwa ibu bekerja memiliki dampak negatif terhadap pembinaaan dan pemeliharaan anak dan bertentangan juga dengan teori Depdiknas (2002) yang menyatakan bahwa ibu bekerja mengurangi waktu dan perhatianya untuk membawa bayinya untuk melakukan imunisasi. Menurut asumsi peneliti hal ini

Faktor - Faktor Yang Berhubungan Dengan Status Imunisasi Dasar Pada Bayi Di 
tidak berhubungan karena saat ini banyak tempat pelayanan kesehatan yang memberikan layanan imunisasi pada sore dan malam hari sehingga ibu yang bekerja terfasilitasi untuk tetap mengimunisasikan bayinya diluar jam kerja ibu.

Tabel 5: Hubungan Dukungan Keluarga dengan Status Imunisasi

\begin{tabular}{lllll}
\hline \multirow{2}{*}{$\begin{array}{l}\text { Dukungan } \\
\text { Keluarga }\end{array}$} & Lengkap & Tidak Lengkap & OR & P value \\
\hline Mendukung & $29(67,4 \%)$ & $14(32,6 \%)$ &, 761 & 0,320 \\
Tidak Mendukung & $20(54,1 \%)$ & $17(45,9 \%)$ & & \\
Jumlah & $49(61,3 \%)$ & $31(38,8 \%)$ & & \\
\hline
\end{tabular}

Hasil analisis hubungan antara dukungan keluarga dengan status imunisasi diketahui bahwa sebanyak $29(67,4 \%)$ ibu yang mendapat dukungan keluarga dan memberikan imunisasi lengkap. Sedangkan ibu yang tidak mendapat dukungan keluarga dan memberikan imunisasi lengkap kepada bayinya 20 responden $(54,1 \%)$. Hasil uji statistik diperoleh nilai $\mathrm{P}=0,320$. Hasil nilai $\mathrm{OR}=$ 1,761 maka dapat disimpulkan bahwa ibu yang mendapat dukungan keluarga berpeluang 1,761 kali memberikan imunisasi lengkap pada bayinya dibanding ibu yang tidak mendapatkan dukungan dari keluarga.Hal ini tidak sesuai dengan teori Lawrence Green (1980) dalam Soekijdo Notoadmojo, 2003 dan Snehandu B.Kar, 1983 yang menyatakan bahwa dukungan keluarga merupakan faktor yang mempengaruhi prilaku.

Hal ini juga tidak sejalan dengan penelitian Rahmawati \& Umbul 2014 yang mendapatkan hasil bahwa faktor yang mempengaruhi kelengkapan imunisasi dasar pada bayi di kelurahan Krembangan Utara, salah satunya adalah dukungan keluarga. Menurut asumsi peneliti, hal ini dimungkinkan karena ibu memiliki motivasi yang tinggi terhadap kesehatan anaknya sehingga ibu tetap memberikan imunisasi lengkap pada anaknya walaupun dukungan yang diberikan oleh keluarga rendah

Tabel 6: Hubungan Tradisi dengan Status Imunisasi

\begin{tabular}{lcccc}
\hline Tradisi & \multicolumn{2}{c}{ Status Imunisasi } & OR & P value \\
& Lengkap & Tidak Lengkap & & \\
\hline Memberi Imunisasi & $10(50 \%)$ & $10(50 \%)$ & 38 & 0,354 \\
Tidak memberi Imunisasi & $39(65 \%)$ & $21(35 \%)$ & & \\
Jumlah & $49(61,3 \%)$ & $31(38,8 \%)$ & & \\
\hline \multicolumn{4}{l}{ Hasil analisis hubungan antara tradisi dengan status imunisasi diketahui }
\end{tabular}

bahwa sebanyak $10(50 \%)$ ibu memiliki tradisi memberikan imunisasi dan mengimunisasikan bayinya secara lengkap. Sedangkan ibu yang memiliki tradisi tidak memberikan imunisasi, sebanyak 39 responden (65\%) yang memberikan imunisasi lengkap pada bayinya. Hasil uji statistik diperoleh nilai $\mathrm{P}=0,354$ maka dapat disimpulkan tidak ada hubungan antara tradisi dengan status imunisasi. Hal ini tidak sejalan dengan hasil penelitian Rahmawati \& Umbul 2014 yang mendapatkan hasil bahwa tradisi merupakan salah satu faktor yang mempengaruhi kelengkapan imunisasi pada bayi. Menurut asumsi peneliti hal ini terjadi karena adanya pembauran budaya dan urbanisasi penduduk sehingga mempengaruhi 
tradisi dan pola pikir untuk berkembang kearah kesehatan akan lebih baik dengan melakukan imunisasi lengkap pada bayinya.

Tabel 7: Hubungan Faktor Sikap dengan Status Imunisasi

\begin{tabular}{llccc}
\hline Sikap & \multicolumn{2}{c}{ Status Imunisasi } & OR & $\begin{array}{c}\text { P } \\
\text { value }\end{array}$ \\
& Lengkap & Tidak Lengkap & & \\
\hline Positif & $28(66,7 \%)$ & $14(33,3 \%)$ & 1,619 & 0,415 \\
Negatif & $21(55,3 \%)$ & $17(44,7 \%)$ & & \\
Jumlah & $49(61,3 \%)$ & $31(38,8 \%)$ & & \\
\hline
\end{tabular}

Hasil analisis hubungan antara faktor sikap dengan status imunisasi diketahuibahwa sebanyak $28(66,7 \%)$ ibu yang memiliki sikap positif terhadap imunisasi memberikan imunisasi lengkap kepada bayinya. Sedangkan lebih dari setengah ibu yang memiliki sikap negatif yaitu 21 responden $(55,3 \%)$ memberikan imunisasi lengkap pada bayinya. Hasil uji statistik diperoleh nilai $\mathrm{P}=0,415$ maka dapat disimpulkan tidak ada hubungan antara sikap dengan status imunisasi. Dari hasil analisis diperoleh $\mathrm{OR}=1,619$ artinya ibu yang mempunyai sikap positif terhadap imunisasi mempunyai peluang 1,619 kali untuk memberikan imunisasi.

Hasil penelitian ini tidak sejalan dengan penelitian Tampemawa yang menyatakan bahwa ada hubungan sikap dengan status imunisasi anak. Menurut asumsi peneliti, karena perilaku dipengaruhi oleh berbagai macam faktor, sehingga walaupun sikap ibu negatif terhadap imunisasi pada bayinya namun ada beberapa faktor lain yang mempengaruhi misalnya lingkungan atau masyarakat sekitar yang memberikan sikap positif terhadap imunisasi.

Tabel 8: Hubungan Informasi dengan Status Imunisasi

\begin{tabular}{|c|c|c|c|c|}
\hline \multirow[t]{2}{*}{ Informasi } & \multicolumn{2}{|c|}{ Status Imunisasi } & \multirow[t]{2}{*}{ OR } & \multirow[t]{2}{*}{$P$ value } \\
\hline & Lengkap & Tidak Lengkap & & \\
\hline Mendapatkan & $4 \quad(44,4 \%)$ & $5(55,6 \%)$ & 0,462 & 0,298 \\
\hline $\begin{array}{l}\text { Tidak } \\
\text { Mendapatkan }\end{array}$ & $45(63,4 \%)$ & $26(36,6 \%)$ & & \\
\hline Jumlah & $49(61,3 \%)$ & $31(38,8 \%)$ & & \\
\hline
\end{tabular}

Hasil analisis hubungan antara informasi dan status imunisasi diketahui bahwa sebanyak $4(44,4 \%)$ ibu yang mendapatkan informasi tentang imunisasi dan memberikan imunisasi lengkap kepada bayinya. Sedangkan diantara ibu yang tidak mendapatkan informasi tentang imunisasi sebanyak 45 responden $(63,4 \%)$ memberikan imunisasi lengkap pada bayinya. Hasil uji statistik diperoleh nilai $\mathrm{P}=0,298$ maka dapat disimpulkan tidak ada hubungan antara informasi dengan status imunisasi.Hasil penelitian ini mendapatkan hasil bahwa tidak ada hubungan antara informasi dengan status imunisasi. WHO (2009) menyatakan bahwa informasi merupakan salahsatu faktor yang berhubungan dengan rendahnya angka imunisasi pada anak. Tidak sejalan juga dengan teori Sneihandu Bkar (1983) bahwa informasi tentang kesehatan atau status kesehatan mempengaruhi perilaku 
kesehatan seseorang. Hal ini tidak sejalan dengan teori dan penelitian diatas, karena menurut asumsi peneliti informasi tidak berhubungan dengan status imunisasi karena walaupun informasi yang diperoleh sedikit namun motivasi yang dimiliki ibu tinggi sehingga ibu tetap memberikan imunisasi pada bayinya.

Tabel 9: Hubungan Motivasi dengan Status Imunisasi

\begin{tabular}{lcccc}
\hline Motivasi & \multicolumn{2}{c}{ Status Imunisasi } & OR & P value \\
& Lengkap & Tidak Lengkap & & \\
\hline Tinggi & $23(69,7 \%)$ & $10(30,3 \%)$ & 1,858 & 0,286 \\
Rendah & $26(55,3 \%)$ & $21(44,7 \%)$ & & \\
Jumlah & $49(61,3 \%)$ & $31(38,8 \%)$ & & \\
\hline
\end{tabular}

Hasil analisis hubungan antara motivasi dengan status imunisasi diketahui bahwa sebanyak 23(69,7 \%) ibu memiliki motivasi tinggi terhadap imunisasi memberikan imunisasi lengkap kepada bayinya. Sedangkan diantara ibu yang memiliki motivasi rendah, sebanyak 26 responden $(55,3 \%)$ yang memberikan imunisasi lengkap pada bayinya. Hasil uji statistik diperoleh nilai $\mathrm{P}=0,286$ maka dapat disimpulkan ada hubungan antara motivasi dengan status imunisasi. Dari hasil analisis diperoleh nilai $\mathrm{OR}=1,858$ artinya ibu yang memiliki motivasi tinggi mempunyai peluang 1,858 kali untuk memberikan imunisasi pada bayinya dibanding ibu yang memiliki motivasi rendah.Hasil penelitian ini tidak sejalan dengan penelitian Ningrum (2008) yang mendapatkan hasil, bahwa motivasi mempengaruhi kelengkapan imunisasi bayi. Motivasi dipandang sebagai dorongan yang menggerakkan dan mengarahkan perilaku manusia, termasuk didalamnya adalah dalam hal belajar, serta motivasi merupakan upaya mengerakkan atau menggugah seseorang agar timbul keinginan atau kemauan untuk melakukan sesuatu sehingga dapat memperoleh hasil atau mencapai tujuan tertentu (Ngalim Purwanto, 2011). Menurut peneliti motivasi tidak hanya didapat dari diri sendiri namun bisa diperoleh dari oranglain ataupun media sosial yang dapat mempengaruhi seseorang untuk berperilaku.

Tabel 10: Hubungan Sarana Kesehatan dengan Status Imunisasi

\begin{tabular}{lcccc}
\hline \multirow{2}{*}{$\begin{array}{l}\text { Sarana } \\
\text { Kesehatan }\end{array}$} & \multicolumn{2}{c}{ Status Imunisasi } & OR & $\begin{array}{c}\text { P } \\
\text { value }\end{array}$ \\
& Lengkap & Tidak Lengkap & & \\
\hline Tersedia & $44(59,5 \%)$ & $30(40,5 \%)$ & 3,409 & 0,397 \\
Tidak tersedia & $5(83,3 \%)$ & $1(16,7 \%)$ & & \\
\hline Jumlah & $49(61,3 \%)$ & $31(38,8 \%)$ & & \\
\hline
\end{tabular}

Hasil analisis hubungan antara sarana kesehatan dengan status imunisasi diketahui bahwa sebanyak 44 (59,5\%) ibu menyatakan bahwa tersedianya sarana kesehatan dan memberikan imunisasi lengkap kepada bayinya. Sedangkan ibu yang menyatakan sarana kesehatan tidak tersedia namun tetap memberikan imunisasi, sebanyak 5 responden ( 83,3\%) memberikan imunisasi lengkap pada bayinya. Hasil uji statistik diperoleh nilai $\mathrm{P}=0,397$ maka dapat disimpulkan tidak ada hubungan antara tradisi dengan status imunisasi. Dari hasil analisis diperolehnilai $\mathrm{OR}=3,409$ artinya ibu yang menyatakan tidak tersedianya sarana

Faktor - Faktor Yang Berhubungan Dengan Status Imunisasi Dasar Pada Bayi Di Desa Rengasdengklok Selatan Kabupaten Karawang 
kesehatan mempunyai peluang 3,409 kali untuk memberikan imunisasi pada bayinya dibanding ibu yang menyatakan tersedianya sarana kesehatan.Asumsi peneliti dikarenakan sarana ini terkait dengan ketersediaan sarana imunisasi berupa vaksin, hal ini dimungkinkan karena terlambatnya distribusi vaksin ke puskesmas sehingga stok vaksin ke posyandu terbatas untuk imunisasi bayi, namun ibu dianjurkan tetap memberikan imunisasi pada bayinya ke puskesmas walaupun asumsi jarak tempuhnya jauh.

Tabel 11: Hubungan Peran Petugas kesehatan dan Status Imunisasi

\begin{tabular}{lcccc}
\hline $\begin{array}{l}\text { Peran petugas } \\
\text { Kesehatan }\end{array}$ & \multicolumn{2}{c}{ Status Imunisasi } & OR & $\begin{array}{c}\text { P } \\
\text { value }\end{array}$ \\
\hline Aktif & $43(59,7 \%)$ & $29(40,3 \%)$ & 0,494 & \\
Tidak aktif & $6(75 \%)$ & $2(25 \%)$ & & \\
Jumlah & $49(61,3 \%)$ & $31(38,8 \%)$ & & \\
\hline
\end{tabular}

Hasil analisis hubungan antara peran petugas kesehatan dengan status imunisasi diketahui bahwa sebanyak $43(59,7 \%)$ ibu yang menyatakan peran petugas kesehatan aktif dan memberikan imunisasi lengkap kepada bayinya. Sedangkan ibu yang menyatakan peran petugas kesehatan tidak aktif dan tetap memberikan imunisasi lengkap kepada bayinya sebanyak 6 responden $(75 \%)$. Hasil uji statistik diperoleh nilai $\mathrm{P}=0,474$ maka dapat disimpulkan tidak ada hubungan antara peran petugas kesehatan dengan status imunisasi. Menurut asumsi peneliti ibu tetap memberikan imunisasi lengkap kepada bayinya karena memiliki motivasi agar anaknya mendapatkan kekebalan dan terhindar dari penyakit, sehingga walaupun petugas kurang berperan aktif namun ibu tetap termotivasi untuk memberikan imunisasi lengkap kepada bayinya.

Tabel 12: Hubungan Jarak Pelayanan kesehatan dengan Status Imunisasi

\begin{tabular}{lcccc}
\hline $\begin{array}{l}\text { Jarak Pelayanan } \\
\text { Kesehatan }\end{array}$ & \multicolumn{2}{c}{ Status Imunisasi } & OR & $\begin{array}{c}\text { P } \\
\text { value }\end{array}$ \\
& Lengkap & Tidak Lengkap & & \\
\hline Dekat & $41(58,6 \%)$ & $29(41,4 \%)$ & 0.353 & 0,301 \\
Jauh & $8(80 \%)$ & $2(20 \%)$ & & \\
Jumlah & $49(61,3 \%)$ & $31(38,8 \%)$ & &
\end{tabular}

Hasil analisis hubungan antara Jarak pelayanan kesehatan dengan status imunisasi diketahui bahwa sebanyak $8(80 \%)$ ibu menyatakan jarak pelayanan kesehatan jauh, namun tetap memberikan imunisasi lengkap kepada bayinya. Sedangkan ibu yang menyatakan jarak pelayanan kesehatan dekat dan memberikan imunisasi lengkap kepada bayinya sebanyak 41 responden $(58,6 \%)$ yang memberikan imunisasi lengkap pada bayinya. Hasil uji statistik diperoleh nilai $\mathrm{P}=0,301$ maka dapat disimpulkan tidak ada hubungan antara jarak pelayanan kesehatan dengan status imunisasi. Hal ini sejalan dengan teori Lauwrace Green dalam Notoadmojo (2003) yang menyatakan bahwa sarana merupakan faktor pendukung perilaku seseorang atau individu. Menurut peneliti karena akses jalan dan transportasi yang baik memungkinkan ibu untuk membawa bayinya untuk mendapatkan imunisasi lengkap ke fasilitas manapun sesuai dengan keinginan individu atau keluarga.

Faktor - Faktor Yang Berhubungan Dengan Status Imunisasi Dasar Pada Bayi Di 


\section{SIMPULAN DAN SARAN}

\section{Simpulan}

Karakteristik ibu di desa Rengasdengklok Selatan yang berjumlah 80 responden, berpendidikan rendah sebanyak 66 orang $(82,5 \%)$, tidak bekerja yaitu $73(91,3 \%)$ responden. Responden yang mendapatkan dukungan keluarga berjumlah 43 responden $(53,8 \%)$. Tradisi tidak melakukan imunisasi didapatkan hasil 60 responden (75\%). Responden memiliki sikap positif sebanyak 42 responden $(52,5 \%)$, tidak mendapatkan informasi tentang imunisasi berjumlah 71 responden $(88,8 \%)$,Responden mempunyai motivasi rendah untuk melakukan imunisasi lengkap kepada bayinya yang berjumlah 47 responden $(58,8 \%)$ dan 74 responden $(92,5 \%)$ menyatakan bahwa sarana kesehatan sudah tersedia untuk melakukan imunisasi lengkap, serta didapatkan hasil bahwa 49 responden $(61,3 \%)$ melakukan imunisasi lengkap kepada bayinya. Faktor-faktor yang terdapat pada variabel independen penelitian ini tidak ada satupun yang berhubungan dengan cakupan status imunisasi lengkap pada bayi. Namun pengetahuan, tradisi dan motivasi merupakan faktor yang berpengaruh secara tidak langsung terhadap kelengkapan status imunisasi pada bayi. Diantara faktor tersebut, motivasi memiliki pengaruh tidak langsung yang besar untuk melakukan imunisasi.

\section{Saran}

Dengan diketahuinya motivasi mempunyai pengaruh tidak langsung terhadap status imunisasi pada bayi, maka dianjurkan kepada setiap ibu yang memiliki bayi agar dapat memotivasi diri sendiri agar bayinya sehat dengan mengupayakan memberikan imunisasi dasar lengkap sesuai jadwal pemberian. Mengoptimalkan kualitas pelayanan asuhan aneonatus dan bayi melalui kegiatan posyandu dengan tetap memberikan motivasi yang terus-menerus melalui penyuluhan individu maupun kelompok tentang pentingnya imunisasi pada bayi dan memotivasi ibu untuk rutin datang ke posyandu serta memberikan imunisasi sesuai jadwal yang sudah ditetapkan.

\section{DAFTAR PUSTAKA}

Ign Ranuh, 2008. Pedoman Imunisasi di Indonesia. Edisi Tiga. Jakarta: Badan Ikatan Dokter anak Indonesia.

Kemenkes, 2013, Buku Ajar Imunisasi.Jakarta

Notoatmodjo, 2003. Metodologi Penelitian Kesehatan, Jakarta : Rineka Cipta.

Nuri Handayani, 2008, Karakteristik Ibu dan Keterjangkauan Imunisasi sebagai Faktor Risiko Ketidaklengkapan Imunisasi Dasar, Skripsi : Universitas Diponegoro Semarang., Vol:2 N, Jurnal Berkala Epidemiologi.

Ningrum, dkk 2014. Faktor-faktor yang Mempengaruhi Kelengkapan Imunisssi Dasar di Puskesmas Banyudono. Jurnal Berita Ilmu Keperwatan. Vol.1 No.1 Maret 2008.

Puskesmas Rengasdengklok, 2017. Profil Puskesmas. Rengasdengklok Karawang. 
Rahmawati, dkk. 2014. Faktor-faktor yang Mempengaruhi Kelengkapan Imunisasi Dasar di Keluarahan Kembangan Utara. Jurnal epidemiologi Berkala, Vol:2 Januari 2014. Hal 59-70.

Tampemawa, 2013. Hubungan Anatara Pengetahuan, Sikap dan Motivasi Ibu Tentang Status Imunisasi Anak Usia 12-24 bulan di Puskesmas Ranotura Wera, Kota Manado.

Umi Khalimah, 2007. Hubungan Antara Karakteristik dan Sikap Ibu Batita Dengan Penerapan Imunisasi Campak di Wilayah kerja Puskesmas Sekaran Gunungpati. Surabaya

Umar Fahmi Achmadi, 2006, Imunisasi Mengapa Perlu, Jakarta : Buku Kompas.

World Health Organization (WHO). 2009. Epidemiologi of The Imuninization Child. Global Immunization, Center Of Desease Control And Prevention Atlanta. 